\title{
Four Stair Ascend Test Functional Test
}

National Cancer Institute

\section{Source}

National Cancer Institute. Four Stair Ascend Test Functional Test. NCI Thesaurus. Code C141689.

A timed function test, one of a series of exercise testing modalities that were initially introduced in the 1960s, that measures functional mobility by assessing the time taken and techniques used to climb four standard-size stairs. 